\title{
Vitamin D deficiency in pregnancy - a failure of public health policy?
}

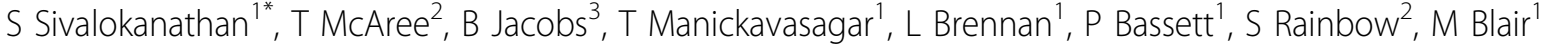 \\ From International Conference for Healthcare and Medical Students 2011 \\ Dublin, Ireland. 4-5 November 2011
}

\section{Introduction}

In order to understand the extent of serum vitamin D deficiency we measured vitamin D levels in an unselected multi-ethnic population of pregnant women. We report the prevalence of insufficiency and deficiency, explore risk factors and discuss the public health implications. This report may be the first of its kind.

\section{Methods}

Sample women with sufficient stored serum were randomly selected from among all women who had delivered in year 2008/09. Serum vitamin D levels were determined using liquid chromatography coupled to tandem mass spectrometry). Vitamin D levels were analyzed with respect to ethnicity (as marker for skin tone), calendar quartile, body mass index trimester and parity. Deficiency was defined as $<25 \mathrm{nmol} / \mathrm{L}$, insufficiency $25-75 \mathrm{nmol} / \mathrm{L}$, and adequacy $>75 \mathrm{nmol} / \mathrm{L}$.

\section{Results}

Three hundred and forty six women were included and represented the total population in terms of skin tone, quartile, BMI, gestation, and parity. Overall, 18\% (95\% CI: $15 \%$ to $23 \%$ ) of sample women had adequate vitamin D levels; $36 \%$ were deficient, $45 \%$ insufficient. Among women with dark skin, only $8 \%$ ( $95 \%$ CI: $5 \%$ to $12 \%$ ) had adequate levels compared to $43 \%$ (95\% CI: $33 \%$ to $53 \%$ ) of those with light skin. Obese women were found have significantly lower Vitamin D levels than non-obese women.

\section{Conclusions}

Vitamin D deficiency and insufficiency are prevalent year round among pregnant women in northwest London, especially those with darker skin. Existing supplementation

IImperial College London, UK

Full list of author information is available at the end of the article guidelines should be supported however; other measures are required to improve status among all women.

\section{Author details \\ ${ }^{1}$ Imperial College London, UK. ${ }^{2}$ North West London Hospital NHS Trust, UK. ${ }^{3} \mathrm{RNOH}$ NHS Trust, Middlesex, UK.}

Published: 9 July 2012

\section{doi:10.1186/1753-6561-6-S4-P9}

Cite this article as: Sivalokanathan et al:: Vitamin D deficiency in pregnancy - a failure of public health policy? BMC Proceedings 20126 (Suppl 4):P9.
Submit your next manuscript to BioMed Central and take full advantage of:

- Convenient online submission

- Thorough peer review

- No space constraints or color figure charges

- Immediate publication on acceptance

- Inclusion in PubMed, CAS, Scopus and Google Scholar

- Research which is freely available for redistribution
C Biomed Central

\section{Biomed Central}

